\title{
"Soft" Calcium Crosslinks Enable Highly Efficient Gene Transfection Using TAT Peptide
}

\author{
Abdulgader Baoum ${ }^{1}$, Sheng-Xue Xie ${ }^{1}$, Amir Fakhari ${ }^{2}$, and Cory Berkland ${ }^{1,3,4}$ \\ ${ }^{1}$ Department of Pharmaceutical Chemistry, The University of Kansas, 2030 Becker Drive, \\ Lawrence, Kansas 66047, USA \\ 2Department of Bioengineering, The University of Kansas, 2030 Becker Drive, Lawrence, Kansas \\ 66047, USA \\ ${ }^{3}$ Department of Chemical and Petroleum Engineering, The University of Kansas, 2030 Becker \\ Drive, Lawrence, Kansas 66047, USA
}

\begin{abstract}
Purpose-Typically, low molecular weight cationic peptides or polymers exhibit poor transfection efficiency due to an inability to condense plasmid DNA into small nanoparticles. Here, efficient gene delivery was attained using TAT/pDNA complexes containing calcium crosslinks.

Methods-Electrostatic complexes of pDNA with TAT or PEI were studied with increasing calcium concentration. Gel electrophoresis was used to determine DNA condensation. The morphology of the complexes was probed by transmission electron microscopy. Transfection efficiency was assessed using a luciferase reporter plasmid. The accessibility of phosphate and amine groups within complexes was evaluated to determine the effect of calcium on structure.
\end{abstract}

Results-TAT/pDNA complexes were condensed into small, 50-100 nm particles by optimizing the concentration of calcium. Complexes optimized for small size also exhibited higher transfection efficiency than PEI polyplexes in A549 cells. TAT and TAT complexes displayed negligible cytotoxicity up to $5 \mathrm{mg} / \mathrm{mL}$, while PEI exhibited high cytotoxicity, as expected. Probing the TAT-Ca/pDNA structure suggested that calcium interacted with both phosphate and amine groups to compact the complexes; however, these "soft" crosslinks could be competitively disrupted to facilitate DNA release.

Conclusion-Small and stable TAT-Ca/pDNA complexes were obtained via "soft" calcium crosslinks leading to sustained gene expression levels higher than observed for control PEI gene vectors. TAT-Ca/pDNA complexes were stable, maintaining particle size and transfection efficiency even in the presence of $10 \%$ of FBS. TAT-Ca complexes offer an effective vehicle offering potential for translatable gene delivery.

(C) 2009 Springer Science + Business Media, LLC

${ }^{4}$ To whom correspondence should be addressed. (berkland@ku.edu). 


\section{Keywords}

A549 cells; gene delivery; plasmid DNA; polyethylenimine; TAT

\section{INTRODUCTION}

Intensive effort has been devoted to develop gene therapy systems capable of overcoming a variety of limitations, including low gene transfection efficiency, toxicity, and in vivo instability (1-7). Nonviral vectors have been given considerable attention as gene delivery vehicles because of their presumed safety, ease of synthesis, relatively unrestricted vector size, low cost, and low degree of immunogenicity in comparison to viral vectors (8). Plasmid DNA complexed with cationic lipids (lipoplexes) and polymers (polyplexes) are the most commonly employed nonviral gene delivery vehicles (9-17). Because naked plasmid DNA does not easily penetrate cellular membranes (18), nonviral gene delivery systems may include agents to improve intracellular delivery in an effort to promote transfection. Finally, gene delivery vehicles are subject to dilution, degradation and elimination in vivo, which amplify the need for safe and efficient gene delivery at high doses of DNA.

New strategies have been put forward to enhance cellular uptake of gene delivery vehicles, among which peptides enhancing cell adhesion and internalization have reached a prominent position (19). Peptide sequences, also designated as protein transduction domains (PTD) or membrane translocalization signals (MTS), were identified as potentially useful labels for intracellular delivery of peptides, proteins, oligonucleotides, and plasmid DNA (20-24). By modifying the surface of gene delivery vectors with cell-penetrating peptides (CPPs), vectors have been shown to traverse the membranes of biological cells within seconds to minutes (25). Polycationic CPPs have even been reported to enhance cell permeability and facilitate the intracellular delivery of nanoparticles (26).

The mechanism of cell entry of CPPs alone or with their cargoes still remains somewhat of an enigma. Some reports indicating that cellular translocation of CPPs is energy as well as endocytosis independent and that there is direct transfer of the peptides through the lipid bilayer by inverted micelle formation (27-32). Another report, however, proposed an energy dependent mechanism of cell entry of CPPs (33), which may also involve extracellular heparan sulfate and various endocytosis and macropinocytosis pathways (34-41). It was also suggested that classical and nonclassical endocytosis pathways may be associated simultaneously with CPP translocation, depending upon the biophysical properties of CPPs and their cargo $(32,42,43)$.

One particular CPP of interest is the HIV-1 TAT peptide. This peptide, which represents a protein transduction domain $(44,45)$ and a nuclear localization sequence (NLS) $(46)$, has been reported to show unusual translocation abilities by directly crossing biological membranes independent of receptors and temperature (47). In addition, the NLS function of TAT peptide could facilitate nuclear localization of a therapeutic agent due to interaction with the endogenous cytoplasmic nuclear transport machinery. The cationic nature of the TAT sequence arising from several arginine residues has already been utilized in gene delivery either by covalent coupling of this CPP to the gene delivery vehicle (48-50) or by 
simple mixing of plasmid DNA with TAT to form TAT/pDNA complexes via noncovalent electrostatic interactions (51-54). However, the transfection efficiency of such complexes remains quite low and requires improvement.

Obviously, a strong affinity between TAT peptide and plasmid DNA is required to stabilize the resulting polyplex and to achieve an optimized transfection yield. On the other hand, a sufficiently low affinity between TAT peptide and plasmid DNA is desired to facilitate the release of the cargo after cellular uptake. Thus, the critical balance between the TAT/pDNA binding affinities has important consequences for enhancing the transfection efficiency. Our objective was to design a more efficient and less toxic means of gene delivery using TAT/ pDNA complexes containing "soft" crosslinks. Calcium was found to control the delicate balance between binding affinities within TAT/pDNA polyplexes. The addition of $\mathrm{CaCl}_{2}$ to TAT/pDNA complexes directly affected particle size and transfection efficiency in a concentration-dependent manner. The optimum calcium concentration $(0.3 \mathrm{M})$ resulted in a 1,000-fold enhancement in TAT/pDNA polyplex transfection efficiency and showed no detectable cytotoxicity. Gene transfection levels were as high as that observed for PEI polyplexes, suggesting the possible translation of the TAT-Ca/pDNA complexes.

\section{MATERIALS AND METHODS}

\section{Materials}

Plasmid DNA encoding firefly luciferase (pGL3, $4.8 \mathrm{kbp}$ ) was obtained from Promega (Madison, WI, USA) and transformed into Escherichia coli DH5á (Invitrogen, Carlsbad, CA). A single transformed colony picked from an agar plate was cultured in LB Broth Base (Invitrogen) liquid for plasmid DNA preparation. Plasmid DNA was purified with Plasmid Giga Kit 5 (Qiagen, Germantown, MD) following the manufacturer's instructions. All pDNA had purity levels of 1.8 or greater as determined by UV/Vis inspection $\left(\mathrm{A}_{260} / \mathrm{A}_{280}\right)$. TAT peptide (RKKRRQRRR; Mw=1338.85 Da, TFA salt=2632.9 Da) was synthesized in house. Branched polyethylenimine (PEI, $25 \mathrm{kDa}$ ) was obtained from Aldrich (Milwaukee, WI). Calcium chloride $\left(\mathrm{CaCl}_{2} \cdot 2 \mathrm{H}_{2} \mathrm{O}\right)$ and agarose medium were purchased from Fisher Scientific (Pittsburgh, PA). A549 cells were obtained from the American Type Culture Collection (ATCC, Rockville, MD). The cell culture medium (Ham's F-12 Nutrient Mixture, Kaighn's modified with L-glutamine) was purchased through Fisher Scientic. Fetal bovine serum (FBS) was purchased from Hyclone. Penicillin-streptomycin was purchased from MB Biomedical, LLC. Trypsin-EDTA was purchased through Gibco. MTS reagent [tetrazolium compound; 3-(4, 5-dimethylthiazol-2-yl)-5-(3-carboxymethoxyphenyl)-2-(4sulfophenyl)-2H-tetrazolium, inner salt] was purchased from Promega. Heparin Sodium was obtained from Spectrum (Gardena, CA).

\section{Preparation of TAT-Ca/pDNA Complexes}

TAT/pDNA complexes were synthesized by rapidly adding $10 \mu \mathrm{L}(0.1 \mu \mathrm{g} / \mu \mathrm{L})$ of pDNA to $15 \mu \mathrm{L}$ (N/P ratio of 25) TAT solution while pipetting. To this solution, $15 \mu \mathrm{L}$ of known molarity (e.g. $0.3 \mathrm{M}$ ) $\mathrm{CaCl}_{2}$ was added and mixed by vigorous pipetting followed by $15-20$ min incubation at $4^{\circ} \mathrm{C}$ prior to use. 


\section{Formation of PEI/pDNA Complexes}

PEI-DNA complexes were prepared by adding $10 \mu \mathrm{l}(0.1 \mu \mathrm{g} / \mu \mathrm{L})$ of pDNA solution to $15 \mu \mathrm{L}$ (N/P ratio of 5 or 10) PEI solution dropwise while stirring. Complexes were incubated at room temperature for 20-30 min before dilution 1.7 times $(15 \mu \mathrm{L})$ with the appropriate buffer (e.g. nuclease-free water or $\mathrm{CaCl}_{2}$ solution). Complexes were freshly prepared before each individual experiment.

\section{Size and Zeta Potential Measurement}

Suspensions containing complexes with TAT or PEI were prepared as described earlier using a DNA concentration of $0.1 \mu \mathrm{g} / \mu \mathrm{L}$. All samples intended for light scattering analyses were prepared using $10 \mathrm{mM}$ Tris buffer, $\mathrm{pH} 7.4$, which was prefiltered with a $0.22 \mu \mathrm{m}$ filter to remove any trace particulates. Particle sizes were measured by dynamic light scattering (DLS) using a Brookhaven (Holtsville, NY) instrument equipped with a 9000AT autocorrelator, a $50 \mathrm{~mW}$ HeNe laser operating at $532 \mathrm{~nm}$ (JDS Uniphase), an EMI 9863 photomultiplier tube, and a BI $200 \mathrm{M}$ goniometer. The light scattered at $90^{\circ}$ from the incident light was fit to an autocorrelation function using the method of cumulants. Zeta potential measurements were obtained by phase analysis light scattering using a Brookhaven Zeta PALS instrument. The electrophoretic mobility of the samples was determined from the average of 10 cycles of an applied electric field. The zeta potential was determined from the electrophoretic mobility from the Smoluchowski approximation. Zeta potential was determined in $1 \mathrm{mM} \mathrm{KCl}$ solution.

\section{Agarose Gel Electrophoresis Assays}

The pDNA binding ability of the TAT, TAT-Ca, $\mathrm{CaCl}_{2}$ and PEI complexes was analyzed by agarose gel electrophoresis. The TAT-Ca/pDNA and PEI/DNA complexes containing $1 \mu \mathrm{g}$ luciferase reporter gene were prepared as described at various N/P ratios. The N/P ratio refers to the molar ratio of amine groups in the cationic polymer, which represent the positive charges, to phosphate groups in the plasmid DNA, which represent the negative charges. The DNA complex suspensions (i.e. $25 \mu \mathrm{L}$ ) at various N/P ratios were diluted by adding $4 \mu \mathrm{L}$ of $10 \times$ Tris-acetate-EDTA (TAE) gel running buffer (Promega) and $4 \mu \mathrm{L}$ of $100 \times$ SYBR Green (Invitrogen) solutions. The DNA loading buffer $(7 \mu \mathrm{L}$ of $6 \times$ ) was added to the complex suspensions. The mixtures were allowed to incubate at room temperature for 40 min to ensure labeling of the DNA with the SYBR Green dye. Thereafter, the complexes were loaded into individual wells of $1 \%$ agarose/ $1 \times$ TAE gel buffer, and subjected to electrophoresis at $110 \mathrm{~V}$ for $30 \mathrm{~min}$. Uncomplexed DNA diluted with an identical volume of solution was used as a control. The resulting DNA migration patterns were revealed using an AlphaImager® Imaging System (Alpha Innotech, San Leandro, CA).

\section{Cell Culture}

Culturing of human epithelial lung cell line A549 was performed according to the protocol provided by the American Type Culture Collection. A549 cells were grown in F-12K supplemented with $10 \% \mathrm{v} / \mathrm{v}$ FBS and $1 \% \mathrm{v} / \mathrm{v}$ Penicillin/streptomycin at $37^{\circ} \mathrm{C}$ in a humidified air atmosphere containing $5 \% \mathrm{CO}_{2}$. 


\section{In Vitro Cell Transfection Studies}

A549 cells were trypsinized, counted and diluted to a concentration of approximately 80,000 cells/ $\mathrm{mL}$. Then $0.1 \mathrm{~mL}$ of that dilution was added to each well of a 96-well plate, and the cells were incubated in a humidified atmosphere at $5 \% \mathrm{CO}_{2}$ and $37^{\circ} \mathrm{C}$ for $24 \mathrm{~h}$. Immediately before transfection, the cells were washed once with PBS and $100 \mu$ l sample (20\% of complex to $80 \%$ of serum-free cell culture medium) was added to each well. Cells were incubated with the complexes for $5 \mathrm{~h}$. The transfection agent was then removed by aspiration, and $100 \mu \mathrm{L}$ of fresh serum medium was added followed by further incubation. The Luciferase Assay System from Promega was used to determine gene expression following the manufacturer's recommended protocol. The light units were normalized against protein concentration in the cells' extracts, which were measured using the Coomassie Plus ${ }^{\mathrm{TM}}$ Protein Assay (Thermo Scientific). The transfection results were expressed as Relative Light Units (RLU) per mg of cellular protein.

\section{Assessment of Cytotoxicity (MTS Assay)}

Cytotoxicity of polymers was determined by the Cell-Titer $96^{\circledR}$ Aqueous Cell Proliferation Assay (Promega). A549 cells were grown as described in the transfection experiments. Cells were treated with the samples for $\sim 24 \mathrm{~h}$. The media were then removed and replaced with a mixture of $100 \mu \mathrm{L}$ fresh culture media and $20 \mu \mathrm{L}$ MTS reagent solution. The cells were incubated for $3 \mathrm{~h}$ at $37^{\circ} \mathrm{C}$ in the $5 \% \mathrm{CO}_{2}$ incubator. The absorbance of each well was then measured at $490 \mathrm{~nm}$ using a microtiter plate reader (SpectraMax, M25, Molecular Devices Corp., CA) to determine cell viability.

\section{SYBR Green Assay of TAT and PEI Complexes}

The degree of pDNA accessibility following complexation with TAT or PEI was assessed by the double-stranded-DNA-binding reagent SYBR Green (Invitrogen). Briefly, $10 \mu \mathrm{L}(0.1$ $\mathrm{mg} / \mathrm{mL}$ ) of pDNA was mixed with $15 \mu \mathrm{L}$ of TAT or PEI solution, then $15 \mu \mathrm{L}$ deionized water or metal solution was added. Complexes were allowed to form for $30 \mathrm{~min}$ at room temperature prior to use. After incubation, $120 \mu \mathrm{L}$ deionized water and $160 \mu \mathrm{L} 10 \times \mathrm{SYBR}$ Green solutions were added. And then $80 \mu \mathrm{L}$ of sample was added to three wells of a 96well cell culture plate. The fluorescence was measured using a fluorescence plate reader (SpectraMax M5; Ex., 250 nm; Em, 520 nm).

\section{TNBS Assay of TAT and PEI Complexes}

The accessibility of free amine groups of TAT or PEI following complexation with pDNA was measured using a colorimetric assay with 2,4,6-trinitro-benzenesulphonic acid (TNBS) as an assay reagent (Pierce). Briefly, $10 \mu \mathrm{L}$ of complex solution was added to $190 \mu \mathrm{L}$ deionized water and then $200 \mu \mathrm{L}$ of $0.02 \%$ TNBS solution in $0.1 \mathrm{M}$ sodium bicarbonate buffer $(\mathrm{pH} 8.5)$ was added. The solution was rapidly mixed. After incubation at $37^{\circ} \mathrm{C}$ for 2 h, $80 \mu \mathrm{L}$ of sample was added to three wells of a 96-well cell culture plate. The absorption at $335 \mathrm{~nm}$ was determined using a plate reader. 


\section{The Effect of Heparin on the Stability of TAT and PEI Complexes}

The effect of heparin on the stability of complexes was evaluated by the means of the change in fluorescence intensity obtained with the fluorescent probe SYBR Green. TAT and PEI complexes were freshly prepared in absence and the presence of $\mathrm{CaCl}_{2}(0.3 \mathrm{M})$ as above described. $120 \mu \mathrm{L}$ of heparin solution was added to these various complexes to yield final diverse heparin concentrations up to $50 \mu \mathrm{g} / \mu \mathrm{L}$, incubated for $30 \mathrm{~min}$ at room temperature and then $160 \mu \mathrm{L} 10 \times$ SYBR Green was added. In triplicate, $80 \mu \mathrm{L}$ of each sample was added to the well of 96-well plate and the fluorescence was measured as indicated in SYBR Green assay.

\section{Statistical Analysis}

Statistical evaluation of comparing the significance of the difference in expression between the means of two groups was performed using the $t$-test, a value of $p<0.05$ was accepted as significant.

\section{RESULTS}

\section{Formation of TAT-Ca/pDNA and PEI/pDNA Complexes}

TAT and PEI complexes were prepared by mixing pDNA with each polycation at various $\mathrm{N} / \mathrm{P}$ ratios as described. In order to demonstrate complex formation, a gel electrophoresis assay was performed using $1 \%$ agarose gel. Uncomplexed pDNA was used as a control. Gel electrophoresis indicated that pDNA complexed with polycations could be retained in the loading wells. Above a certain N/P ratio, no bands were observed during electrophoresis, indicating that TAT and PEI completely complexed the pDNA. Under these conditions, $\mathrm{CaCl}_{2}$ showed negligible ability to complex the plasmid DNA even at high concentration (1 M) (Fig. 1).

\section{Morphological and Physical Characterization of TAT-Ca/pDNA and PEI/pDNA Complexes}

The effect of calcium chloride concentration on the particle size and surface charge of TAT/ pDNA and PEI/pDNA complexes was investigated. Over a certain concentration range, calcium addition to TAT/pDNA complexes induced a substantial decrease in the particle size. In comparison, PEI/pDNA complexes showed an increase in particle size (Fig. 2A). The added $\mathrm{CaCl}_{2}$ concentration range of $0.3-0.5 \mathrm{M}\left(113-188 \mathrm{mM}\right.$ final $\mathrm{CaCl}_{2}$ concentration) produced small $(50-100 \mathrm{~nm})$ and stable TAT/pDNA complexes with relatively narrow polydispersity $(<0.15)$. In general, the zeta potential of TAT and PEI complexes increased significantly from 11 to $27 \mathrm{mV}$ with increasing concentration of $\mathrm{CaCl}_{2}$ (Fig. 2B).

A transmission electron microscope (FEI field emission transmission electron microscope, Tecnai $\mathrm{G}^{2}$ at $200 \mathrm{kV}$ ) equipped with an energy-dispersive analytical X-ray (EDAX) was used to image the morphology of the TAT/pDNA and TAT-Ca/pDNA complexes and to characterize elements in these complexes, respectively. TEM samples were prepared by depositing a drop of the complex suspension on a copper carbon grid and allowing it to dry in a dessicater overnight. Transmission electron micrographs of TAT/pDNA complexes revealed an asymmetric morphology. The darker areas in TAT-Ca/pDNA seemed to suggest 
calcium trapped inside the particles (Fig. 3A and B). Samples were imaged using scanning transmission electron microscopy and analyzed using EDAX spectroscopy to detect the location of calcium. EDAX spectrum for two labeled areas in the scanning transmission electron micrograph (on the particles and substrate) revealed significantly higher calcium concentration in the particles compared to free calcium that would have dried on the substrate (Fig. 4A, B and C).

The stability of TAT and PEI complexes was investigated as a function of time in the absence and presence of $0.3 \mathrm{M} \mathrm{CaCl}_{2}$ and 10\% FBS (Fig. 5A and B). TAT/pDNA complexes including $0.3 \mathrm{M} \mathrm{CaCl}_{2}$ remained stable in the absence and presence of $10 \% \mathrm{FBS}$ over a period of 8 days. Conversely, PEI/pDNA complexes showed a marked increase in size.

\section{Cytotoxicity of TAT and PEI Complexes}

Low cytotoxicity together with high transfection efficiency are extremely important attributes for nonviral gene vectors. The cytotoxicity of free TAT, PEI, and $\mathrm{CaCl}_{2}$ was studied by incubating A549 cells with up to $5 \mathrm{mg} / \mathrm{mL}$ of TAT or PEI and with up to $0.5 \mathrm{M}$ $\mathrm{CaCl}_{2}$ (Fig. 6A and B). TAT peptide revealed no evidence of cytotoxicity, and cells maintained high viability. Branched PEI induced significant cytotoxicity ( $\mathrm{IC}_{50} \sim 35 \mu \mathrm{g} / \mathrm{mL}$ ). $\mathrm{CaCl}_{2}$ alone showed modest cytotoxicity $\left(\mathrm{IC}_{50} \sim 210 \mathrm{mM}\right)$.

\section{In Vitro Transfection Efficiency of TAT-Ca/pDNA and PEI/pDNA Complexes}

The in vitro transfection efficiency of these complexes was studied using the human lung carcinoma cell line A549. Luciferase gene expression was evaluated on day 1 of transfection using the TAT or PEI polyplexes including different concentrations of $\mathrm{CaCl}_{2}$ during the complex formation. TAT complexes showed a higher level of gene expression at $0.3 \mathrm{M}$ $\mathrm{CaCl}_{2}$ when compared to PEI, which had excellent transfection efficiency in the absence of $\mathrm{CaCl}_{2}$ (Fig. 7). It was interesting that the optimized level of gene expression of TAT-Ca/ pDNA complexes was similar to the transfection efficiency of branched PEI and increased over the first four days. Conversely, the gene expression of PEI/pDNA complexes showed a marked decrease during the same time-frame. The gene expression was sustained for at least 10 days, and TAT-Ca/pDNA complexes appeared to be superior to PEI/DNA complexes at day 8 and 10 (Fig. 8). Strikingly, no expression was observed for TAT/pDNA complexes without $\mathrm{CaCl}_{2}$. In addition, $\mathrm{PEI}-\mathrm{Ca} / \mathrm{pDNA}$ complexes exhibited lower levels of gene expression compared to PEI/pDNA complexes. It is important to note that the optimum gene transfection for TAT-Ca/pDNA complexes occurred when $0.3 \mathrm{M}$ of $\mathrm{CaCl}_{2}$ was added, which yields a final $\mathrm{CaCl}_{2}$ concentration of $113 \mathrm{mM}$, well below the $\mathrm{CaCl}_{2} \mathrm{IC}_{50}$ value of $210 \mathrm{mM}$.

\section{The Effect of Serum on Transfection Efficiency and Particle Size}

It has been previously reported that the presence of serum may have a significant influence on the transfection efficiency of nonviral gene delivery vehicles (55-57). To determine the effect of serum on gene expression, A549 cells were transfected with optimized TAT-Ca/ pDNA $\left(0.3 \mathrm{M} \mathrm{CaCl}_{2}\right)$ or PEI/pDNA complexes in the absence and presence of $10 \% \mathrm{FBS}$. Results indicated that serum did not significantly inhibit the transfection efficiency mediated 
by TAT-Ca/pDNA complexes. In contrast, PEI complexes showed slightly decreased transfection efficiency in the presence of 10\% FBS (Fig. 9). The effect of serum on transfection efficiency should be considered in light of the stability of the size of TAT and PEI complexes which were investigated as a function of time. TAT/pDNA complexes without $\mathrm{CaCl}_{2}$ exhibited some agglomeration behavior in the absence and presence of $10 \%$ of FBS after 8 days (Fig. 5A and B). However, TAT-Ca/pDNA complexes showed good stability in serum-free and supplemented culture media during the same time-frame. On the other hand, $\mathrm{PEI} / \mathrm{pDNA}$ complexes remained stable in the absence of serum and $\mathrm{CaCl}_{2}$ over a period of 8 days and retained their size, whereas the particle size of PEI-Ca/pDNA showed a marked decrease during the same time-frame in the presence of serum.

\section{SYBR Green Assay}

Dye displacement assays provide a simple, nondestructive, and high throughput method for investigating the pDNA accessibility within complexes. Various concentrations of $\mathrm{CaCl}_{2}$ were examined to identify the effect on pDNA packaging. SYBR green, which binds double-stranded DNA, was used for the assay (58). TAT/pDNA complexes showed weak fluorescence intensity. The addition of different $\mathrm{CaCl}_{2}$ concentrations up to $0.3 \mathrm{M}$ likely condensed the TAT complexes, which resulted in lowering the accessibility of pDNA (Fig. 10A). The fluorescence intensity transitioned into a gradual increase with increasing concentration of $\mathrm{CaCl}_{2}$. In contrast, $\mathrm{PEI} / \mathrm{pDNA}$ complexes exhibited a negligible fluorescence for all concentrations of $\mathrm{CaCl}_{2}$ except at 0 and $2 \mathrm{M} \mathrm{CaCl}_{2}$, where slight fluorescence intensities were observed.

\section{TNBS Assay}

A TNBS assay was also used to determine the accessibility of the primary amine groups within the TAT/pDNA or PEI/pDNA complexes. The TNBS assay revealed that the free TAT had more primary amine groups than PEI, which decreased to negligible levels when adding the designated volume of $0.3 \mathrm{M} \mathrm{CaCl}_{2}$ to them (Fig. 10B). Control studies indicated that adding $62.5 \mathrm{mM} \mathrm{CaCl}_{2}$ decreased the absorption intensity of TNBS by less than $10 \%$. Increasing $\mathrm{CaCl}_{2}$ concentration did not affect the absorption intensity further. These results supported the hypothesis that the efficiency of DNA compaction was increased by the introduction of $\mathrm{CaCl}_{2}$. Therefore, calcium interaction with amines also facilitated the observed stabilization and decrease in particle size for TAT/pDNA complexes. PEI complexes including $\mathrm{CaCl}_{2}$ showed low binding of the dye as well, but this may result from particle agglomeration or precipitation as suggested by the particle size studies.

\section{Stability of Complexes Exposed to Heparin}

The stability of TAT and PEI complexes when exposed to the biological polyanion heparin was studied by determining changes in the SYBR Green-pDNA fluorescence. Exposing the complexes to heparin yielded an increase in the fluorescence signal as the heparin concentration increased (Fig. 11). TAT and PEI complexes including $0.3 \mathrm{M} \mathrm{CaCl}_{2}$ showed release of the plasmid DNA from the complexes at lower heparin concentrations than without calcium. These results indicated that calcium may control the delicate balance between binding affinities within polycations and pDNA complexes. 


\section{DISCUSSION}

Improvement in the field of gene therapy is currently hindered by the lack of translatable gene delivery vectors. Synthetic, nonviral, vehicles based on polycations are promising vectors for gene delivery (59-64). The toxicity of these materials may be reduced or eliminated by reducing polycation molecular weight. However, the levels of gene expression mediated by low molecular weight polycations are typically low compared to higher molecular weight polycations (e.g. $25 \mathrm{kDa}$ PEI) $(65,66)$. As a result, many researchers have aimed to improve upon the deficiency of either system.

Among nonviral vehicles, cell-penetrating peptides (CPPs) have been used to deliver a variety of therapeutics. For example, experimental anti-cancer cargo including small molecules, proteins and nucleic acids, were delivered into cells in vitro using CPPs and have been explored to treat preclinical tumor models in vivo $(67,68)$. Complexes of plasmid DNA with TAT peptides have been used in gene delivery either by covalent coupling of the peptide to the vectors, or by simple mixing of the plasmid DNA with the TAT peptide to form TAT/pDNA complexes via electrostatic interactions. However, the transfection efficiency for these complexes was quite low in comparison to PEI.

In our studies, TAT/pDNA complexes alone also exhibited no gene expression. The size of these complexes was quite large $(\sim 1,000 \mathrm{~nm})$ for gene delivery. Therefore, calcium was explored as a condensing agent to reduce the size of TAT/pDNA complexes and to improve transfection efficiency. Calcium was found to form tight and compact complexes ( $60 \mathrm{~nm})$ through "soft" crosslinks that could be competitively disrupted in order to increase transfection efficiency. The precise balance between binding affinities within TAT/pDNA polyplexes was adjusted by controlling $\mathrm{CaCl}_{2}$ concentration as a means to optimize transfection efficiency. Previous studies have shown that both small and larges particles may provide efficient levels of gene expression (69-72). However, the condensed size of TAT$\mathrm{Ca} / \mathrm{pDNA}$ complexes in this study appeared to correlate with enhanced transfection efficiency.

The ability of calcium to condense TAT/pDNA complexes occurred as a result of calcium interactions with both amines (polycations) and phosphates (DNA). The binding affinity of calcium to double-stranded DNA was observed as indicated by gel electrophoresis of the TAT-Ca/pDNA complexes. A specific $\mathrm{CaCl}_{2}$ concentration range was necessary to achieve small particles. Dye displacement studies provided some indication of the extent of compaction of DNA when bound to TAT or PEI. Nearly complete exclusion of TNBS from both TAT/pDNA and PEI/pDNA complexes was achieved when $0.3 \mathrm{M}$ calcium was added to the polyplexes, suggesting that the primary amine groups within these complexes were blocked. Moreover, pDNA was mostly inaccessible to SYBR green when TAT/pDNA complexes were formulated with up to $0.3 \mathrm{M} \mathrm{CaCl}_{2}$, suggesting that pDNA was also extensively condensed within the complexes. The accessibility of pDNA increased at higher concentrations of $\mathrm{CaCl}_{2}$ which demonstrated that calcium may also competitively inhibit the amine/phosphate interaction. 
The stability of TAT and PEI complexes upon exposure to the polyanion heparin revealed that complex dissociation depended on the inclusion of calcium as well. Heparin and heparan sulfate have been previously reported to bind to PEI and release pDNA from complexes $(73,74)$. Complex stability is significant because sufficiently low affinity between polycation and plasmid DNA may be desirable to facilitate the release of the DNA after cellular uptake. The inclusion of calcium in the formulation of TAT and PEI complexes facilitated the dissociation of these complexes by heparin. Therefore, the release of pDNA from the complexes suggested that a critical concentration of calcium can condense the complexes into small particles yet facilitate the release of DNA.

A successful gene delivery system should be able to deliver DNA to the cell without negatively affecting the viability of the host cell. A cytotoxicity study in A549 human lung carcinoma cells indicated that TAT peptide provided substantially higher cell viability than PEI. Further studies will be necessary to determine if this gene vector is benign in primary human cells.

\section{CONCLUSION}

Drug delivery strategies using CPPs such as TAT have been widely explored to improve the intracellular delivery of a large number of cargo molecules. Electrostatic complexation of pDNA using TAT has been less explored due to the relatively low levels of gene expression observed when using such low molecular weight polycations as DNA condensing agents. We have found that the binding affinity of calcium for TAT peptide and pDNA can be used to effectively mediate the charge balance within these complexes. In this study, it was shown that $0.3 \mathrm{M} \mathrm{CaCl}_{2}$ produced small and stable TAT/pDNA complexes via "soft" crosslinks leading to gene expression levels higher than observed for control PEI gene vectors in A549 lung epithelial cells. TAT-Ca/pDNA complexes were stable, maintaining particle size in the absence and presence of $10 \%$ of FBS over a period of 8 days. Gene expression of TAT-Ca/pDNA complexes was sustained for at least 10 days and tended to increase over the first four days of the study. Conversely, gene expression levels for PEI/ pDNA complexes showed high initial gene expression that dropped to low levels after day 4 . Moreover, the transfection efficiency of TAT-Ca/pDNA complexes was not significantly influenced by the presence of serum. The TAT peptide also showed negligible cytotoxicity up to $5 \mathrm{mg} / \mathrm{mL}$. In comparison, PEI was very cytotoxic $\left(\mathrm{IC}_{50} \sim 35 \mu \mathrm{g} / \mathrm{mL}\right)$. Thus, these data suggest that TAT-Ca complexes are a novel and effective vehicle offering some potential for translatable gene delivery.

\section{Acknowledgments}

We would like to acknowledge support for this work from the Coulter Foundation, the Higuchi Biosciences Center, and the Cystic Fibrosis Foundation as well as additional lab funding from the American Heart Association, the NIH (R03 AR054035, P20 RR016443 and T32 GM08359-11) and the Department of Defense. In addition, we acknowledge the support of the NSF (CHE 0719464). We also thank Prof. C. Russ Middaugh for the use of laboratory equipment and the Microscopy Lab for assistance with electron microscopy.

\section{REFERENCES}

1. Check E. A tragic setback. Nature. 2002; 420:116-118. [PubMed: 12432357] 
2. Felgner PL. Nonviral strategies for gene therapy. Sci Am. 1997; 276:102-106. [PubMed: 9163942]

3. Hope MJ, Mui B, Ansell S, Ahkong QF. Cationic lipids, phosphatidylethanolamine and the intracellular delivery of polymeric, nucleic acid-based drugs (Review). Mol Membr Biol. 1998; 15:1-14. [PubMed: 9595549]

4. Marshall E. Clinical trials: gene therapy death prompts review of adenovirus vector. Science. 1999; 286:2244. [PubMed: 10636774]

5. Peeters M, Patijn GA, Lieber A, Meuse L, Kay MA. Adenovirus-mediated hepatic gene transfer in mice: comparison of intravascular and biliary administration. Hum Gene Ther. 1996; 7:1693-1699. [PubMed: 8886840]

6. Thomasand M, Klibanov AM. Non-viral gene therapy: polycation-mediated DNA delivery. Appl Microbiol Biotechnol. 2003; 62:27-34. [PubMed: 12719940]

7. Yei S, Mittereder N, Tang K, O’Sullivan C, Trapnell BC. Adenovirus-mediated gene transfer for cystic fibrosis: quantitative evaluation of repeated in vivo vector administration to the lung. Gene Ther. 1994; 1:192-200. [PubMed: 7584081]

8. Huang, L.; Hung, M.; Wagner, E. Nonviral Vectors for Gene Therapy. Academic; 1999.

9. Davis ME. Non-viral gene delivery systems. Curr Opin Biotechnol. 2002; 13:128-131. [PubMed: 11950563]

10. Felgner PL, Gadek TR, Holm M, Roman R, Chan HW, Wenz M, et al. Lipofection: a highly efficient, lipid-mediated DNA-transfection procedure. Proc Natl Acad Sci. 1987; 84:7413-7417. [PubMed: 2823261]

11. Hofland HEJ, Nagy D, Liu JJ, Spratt K, Lee YL, Danos O, et al. In vivo gene transfer by intravenous administration of stable cationic Lipid/DNA complex. Pharm Res. 1997; 14:742-749. [PubMed: 9210191]

12. Hortobagyi GN, Ueno NT, Xia W, Zhang S, Wolf JK, Putnam JB, et al. Cationic liposomemediated E1A gene transfer to human breast and ovarian cancer cells and its biologic effects: a Phase I clinical trial. J Clin Oncol. 2001; 19:3422. [PubMed: 11454891]

13. Med JG. Lipid-mediated siRNA delivery down-regulates exogenous gene expression in the mouse brain at picomolar levels. J Gene Med. 2005; 7:198-207. [PubMed: 15515135]

14. Ogrisand M, Wagner E. Targeting tumors with non-viral gene delivery systems. Drug Discov Today. 2002; 7:479-485. [PubMed: 11965397]

15. Templeton NS, Lasic DD, Frederik PM, Strey HH, Roberts DD, Pavlakis GN. Improved DNA: liposome complexes for increased systemic delivery and gene expression. Nat Biotechnol. 1997; 15:647-652. [PubMed: 9219267]

16. Sambrook, J.; Russell, DW. Molecular cloning: A laboratory manual. 3rd ed.. Vol. 16. Cold Spring Harbor: Cold Spring Harbor Lab; 2001. Introducing cloned gene into cultured mammalian cells; p. 16.14-16.19.

17. Tang MX, Redemann CT, Szoka FC. In vitro gene delivery by degraded polyamidoamine dendrimers. Bioconjug Chem. 1996; 7:703-714. [PubMed: 8950489]

18. Godbey WT, Wu KK, Mikos AG. Poly (ethylenimine) and its role in gene delivery. J Control Release. 1999; 60:149-160. [PubMed: 10425321]

19. Lundberg M, Wikström S, Johansson M. Cell surface adherence and endocytosis of protein transduction domains. Molec Ther. 2003; 8:143-150. [PubMed: 12842437]

20. Tungand $\mathrm{CH}$, Weissleder R. Arginine containing peptides as delivery vectors. Adv Drug Deliv Rev. 2003; 55:281-294. [PubMed: 12564981]

21. Cao G, Pei W, Ge H, Liang Q, Luo Y, Sharp FR, et al. In vivo delivery of a Bcl-xL fusion protein containing the TAT protein transduction domain protects against ischemic brain injury and neuronal apoptosis. J Neurosci. 2002; 22:5423. [PubMed: 12097494]

22. Dietzand GPH, Bdhr M. Delivery of bioactive molecules into the cell: the Trojan horse approach. Mol Cell Neurosci. 2004; 27:85-131. [PubMed: 15485768]

23. Guptaand B, Torchilin VP. Transactivating transcriptional activator-mediated drug delivery. Expert Opin Drug Deliv. 2006; 3:177-190. [PubMed: 16506946]

24. Schwarze SR, Ho A, Vocero-Akbani A, Dowdy SF. In vivo protein transduction: delivery of a biologically active protein into the mouse. Science. 1999; 285:1569. [PubMed: 10477521] 
25. Schwarze SR, Hruska KA, Dowdy SF. Protein transduction: unrestricted delivery into all cells? Trends Cell Biol. 2000; 10:290-295. [PubMed: 10856932]

26. Koch AM, Reynolds F, Merkle HP, Weissleder R, Josephson L. Transport of surface-modified nanoparticles through cell mono-layers. ChemBioChem. 2005; 6:337-345. [PubMed: 15651046]

27. Derossi D, Calvet S, Trembleau A, Brunissen A, Chassaing G, Prochiantz A. Cell internalization of the third helix of the Antennapedia homeodomain is receptor-independent. J Biol Chem. 1996; 271:18188. [PubMed: 8663410]

28. Deshayes S, Heitz A, Morris MC, Charnet P, Divita G, Heitz F. Insight into the mechanism of internalization of the cell-penetrating carrier peptide Pep-1 through conformational analysis. Biochemistry. 2004; 43:1449-1457. [PubMed: 14769021]

29. Henriques ST, Costa J, Castanho M. Translocation of $\beta$-galactosidase mediated by the cellpenetrating peptide Pep-1 into lipid vesicles and human HeLa cells is driven by membrane electrostatic potential. Biochemistry. 2005; 5:9.

30. Mano M, Teodosio C, Paiva A, Simoes S, de Lima MCP. On the mechanisms of the internalization of S413-PV cell-penetrating peptide. Biochem J. 2005; 390:603. [PubMed: 15907190]

31. Patel LN, Zaro JL, Shen WC. Cell penetrating peptides: intracellular pathways and pharmaceutical perspectives. Pharm Res. 2007; 24:1977-1992. [PubMed: 17443399]

32. Vives E, Richard JP, Rispal C, Lebleu B. TAT peptide internalization: seeking the mechanism of entry. Current Protein and Peptide Science. 2003; 4:125-132. [PubMed: 12678851]

33. Console S, Marty C, Garcia-Echeverria C, Schwendener R, Ballmer-Hofer K. Antennapedia and HIV transactivator of transcription (TAT) "Protein transduction domains" promote endocytosis of high molecular weight cargo upon binding to cell surface glycosaminoglycans. J Biol Chem. 2003; 278:35109-35114. [PubMed: 12837762]

34. Foerg C, Ziegler U, Fernandez-Carneado J, Giralt E, Rennert R, Beck-Sickinger AG, et al. Decoding the entry of two novel cell-penetrating peptides in HeLa cells: lipid raft-mediated endocytosis and endosomal escape. Biochemistry. 2005; 44:72-81. [PubMed: 15628847]

35. Gerbal-Chaloin S, Gondeau C, Aldrian-Herrada G, Heitz F, Gauthier-Rouviere C, Divita G. First step of the cell-penetrating peptide mechanism involves Rac1 GTPase-dependent actin-network remodelling. Biol Cell. 2007; 99:223-238. [PubMed: 17233629]

36. Jones AT. Macropinocytosis: searching for an endocytic identity and role in the uptake of cell penetrating peptides. J Cell Mol Med. 2007; 11:670-684. [PubMed: 17760832]

37. Nakase I, Tadokoro A, Kawabata N, Takeuchi T, Katoh H, Hiramoto K, et al. Interaction of arginine-rich peptides with membrane-associated proteoglycans is crucial for induction of actin organization and macropinocytosis. Biochemistry. 2007; 46:492-501. [PubMed: 17209559]

38. Richard JP, Melikov K, Brooks H, Prevot P, Lebleu B, Chernomordik LV. Cellular uptake of unconjugated TAT peptide involves clathrin-dependent endocytosis and heparan sulfate receptors. J Biol Chem. 2005; 280:15300. [PubMed: 15687490]

39. Silhol M, Tyagi M, Giacca M, Lebleu B, Vives E. Different mechanisms for cellular internalization of the HIV-1 Tat-derived cell penetrating peptide and recombinant proteins fused to Tat. Eur J Biochem. 2002; 269:494-501. [PubMed: 11856307]

40. Thorén PEG, Persson D, Isakson P, Goksor M, Onfelt A, Nordén B. Uptake of analogs of penetratin, Tat (48-60) and oligoarginine in live cells. Biochem Biophys Res Commun. 2003; 307:100-107. [PubMed: 12849987]

41. Wadia JS, Stan RV, Dowdy SF. Transducible TAT-HA fusogenic peptide enhances escape of TAT-fusion proteins after lipid raft macropinocytosis. Nat Med. 2004; 10:310-315. [PubMed: 14770178]

42. Jarver P, Langel Ü. Cell-penetrating peptides-a brief introduction. BBA-Biomembranes. 2006; 1758:260-263. [PubMed: 16574060]

43. Mae M, Myrberg H, Jiang Y, Paves H, Valkna A, Langel Ü. Internalisation of cell-penetrating peptides into tobacco protoplasts. BBA-Biomembranes. 2005; 1669:101-107. [PubMed: 15893512]

44. Fawell S, Seery J, Daikh Y, Moore C, Chen LL, Pepinsky B, et al. Tat-mediated delivery of heterologous proteins into cells. Proc Natl Acad Sci. 1994; 91:664-668. [PubMed: 8290579] 
45. Frankeland AD, Pabo CO. Cellular uptake of the tat protein from human immunodeficiency virus. Cell. 1988; 55:1189-1193. [PubMed: 2849510]

46. Truantand R, Cullen BR. The arginine-rich domains present in human immunodeficiency virus type 1 Tat and Rev function as direct Importin $\beta$-dependent nuclear localization signals. Mol Cell Biol. 1999; 19:1210-1217. [PubMed: 9891055]

47. Vives E, Brodin P, Lebleu B. A truncated HIV-1 Tat protein basic domain rapidly translocates through the plasma membrane and accumulates in the cell nucleus. J Biol Chem. 1997; 272:16010-16017. [PubMed: 9188504]

48. Eguchi A, Akuta T, Okuyama H, Senda T, Yokoi H, Inokuchi H, et al. Protein transduction domain of HIV-1 Tat protein promotes efficient delivery of DNA into mammalian cells. J Biol Chem. 2001; 276:26204-26210. [PubMed: 11346640]

49. Torchilin VP, Rammohan R, Weissig V, Levchenko TS. TAT peptide on the surface of liposomes affords their efficient intracellular delivery even at low temperature and in the presence of metabolic inhibitors. Proc Natl Acad Sci. 2001; 98:8786. [PubMed: 11438707]

50. Tungand $\mathrm{CH}$, Stein S. Preparation and applications of peptide-oligonucleotide conjugates. Bioconjug Chem. 2000; 11:605-618. [PubMed: 10995203]

51. Futaki S, Ohashi W, Suzuki T, Niwa M, Tanaka S, Ueda K, et al. Stearylated arginine-rich peptides: a new class of transfection systems. Bioconjug Chem. 2001; 12:1005-1011. [PubMed: 11716693]

52. Ignatovich IA, Dizhe EB, Pavlotskaya AV, Akifiev BN, Burov SV, Orlov SV, et al. Complexes of plasmid DNA with basic domain 47-57 of the HIV-1 Tat protein are transferred to mammalian cells by endocytosis-mediated pathways. J Biol Chem. 2003; 278:42625-42636. [PubMed: 12882958]

53. Sandgren S, Cheng F, Belting M. Nuclear targeting of macromolecular polyanions by an HIV-Tat derived peptide. Role for cell-surface proteoglycans. J Biol Chem. 2002; 277:38877-38883. [PubMed: 12163493]

54. Tung $\mathrm{CH}$, Mueller S, Weissleder R. Novel branching membrane translocational peptide as gene delivery vector. Bioorg Med Chem. 2002; 10:3609-3614. [PubMed: 12213476]

55. Haberland A, Knaus T, Zaitsev SV, Buchberger B, Lun A, Haller H, et al. Histone H1-mediated transfection: serum inhibition can be overcome by Ca2+ Ions. Pharm Res. 2000; 17:229-235. [PubMed: 10751040]

56. Nchinda G, Uberla K, Zschornig O. Characterization of cationic lipid DNA transfection complexes differing in susceptability to serum inhibition. BMC Biotechnol. 2002; 2:12. [PubMed: 12113654]

57. Zelphati O, Uyechi LS, Barron LG, Szoka FC. Effect of serum components on the physicochemical properties of cationic lipid/oligonucleotide complexes and on their interactions with cells. Biochim Biophys Acta (BBA)/Lipids Lipid Metab. 1998; 1390:119-133.

58. Kwon DS, Lin CH, Chen S, Coward JK, Walsh CT, Bollinger JM Jr. Dissection of glutathionylspermidine synthetase/amidase from Escherichia coli into autonomously folding and functional synthetase and amidase domains. J Biol Chem. 1997; 272:2429. [PubMed: 8999955]

59. Abdallah B, Hassan A, Benoist C, Goula D, Behr JP, Demeneix BA. A powerful nonviral vector for in vivo gene transfer into the adult mammalian brain: polyethylenimine. Hum Gene Ther. 1996; 7:1947-1954. [PubMed: 8930654]

60. Boussif O, Lezoualc'h F, Zanta MA, Mergny MD, Scherman D, Demeneix B, et al. A versatile vector for gene and oligonucleotide transfer into cells in culture and in vivo: polyethylenimine. Proc Natl Acad Sci. 1995; 92:7297-7301. [PubMed: 7638184]

61. Huang CY, Ma SS, Lee S, Radhakrishnan R, Braun CS, Choosakoonkriang S, et al. Enhancements in gene expression by the choice of plasmid DNA formulations containing neutral polymeric excipients. J Pharm Sci. 2002; 91:1371-1381. [PubMed: 11977113]

62. Lobo BA, Vetro JA, Suich DM, Zuckermann RN, Middaugh CR. Structure/function analysis of peptoid/lipitoid: DNA complexes. J Pharm Sci. 2003; 92:1905-1918. [PubMed: 12950008]

63. Tiyaboonchai W, Woiszwillo J, Middaugh CR. Formulation and characterization of DNApolyethylenimine-dextran sulfate nanoparticles. Eur J Pharm Sci. 2003; 19:191-202. [PubMed: 12885383] 
64. Wiethoff CM, Koe JG, Koe GS, Middaugh CR. Compositional effects of cationic lipid/DNA delivery systems on transgene expression in cell culture. J Pharm Sci. 2004; 93:108-123. [PubMed: 14648641]

65. Choosakoonkriang S, Lobo BA, Koe GS, Koe JG, Middaugh CR. Biophysical characterization of PEI/DNA complexes. J Pharm Sci. 2003; 92:1710-1722. [PubMed: 12884257]

66. Forrest ML, Koerber JT, Pack DW. A degradable polyethylenimine derivative with low toxicity for highly efficient gene delivery. Bioconjug Chem. 2003; 14:934-940. [PubMed: 13129396]

67. Lindsay MA. Peptide-mediated cell delivery: application in protein target validation. Curr Opin Pharmacol. 2002; 2:587-594. [PubMed: 12324264]

68. Snyderand EL, Dowdy SF. Cell penetrating peptides in drug delivery. Pharm Res. 2004; 21:389393. [PubMed: 15070086]

69. Pouton CW, Lucas P, Thomas BJ, Uduehi AN, Milroy DA, Moss SH. Polycation-DNA complexes for gene delivery: a comparison of the biopharmaceutical properties of cationic polypeptides and cationic lipids. J Control Release. 1998; 53:289-299. [PubMed: 9741937]

70. Simberg D, Danino D, Talmon Y, Minsky A, Ferrari ME, Wheeler CJ, et al. Phase behavior, DNA ordering, and size instability of cationic lipoplexes. Relevance to optimal transfection activity. J Biol Chem. 2001; 276:47453-47459. [PubMed: 11564736]

71. Turek J, Dubertret C, Jaslin G, Antonakis K, Scherman D, Pitard B. Formulations which increase the size of lipoplexes prevent serum-associated inhibition of transfection. J Gene Med. 2000; 2:32-40. [PubMed: 10765503]

72. Wagner E, Cotten M, Foisner R, Birnstiel ML. Transferrinpolycation-DNA complexes: the effect of polycations on the structure of the complex and DNA delivery to cells. Proc Natl Acad Sci. 1991; 88:4255-4259. [PubMed: 2034670]

73. Moret I, Esteban Peris J, Guillem VM, Benet M, Revert F, Dasi F, et al. Stability of PEI-DNA and DOTAP-DNA complexes: effect of alkaline $\mathrm{pH}$, heparin and serum. J Control Release. 2001; 76:169-181. [PubMed: 11532322]

74. Ruponen M, Yla-Herttuala S, Urtti A. Interactions of polymeric and liposomal gene delivery systems with extracellular glycosaminoglycans: physicochemical and transfection studies. BBABiomembranes. 1999; 1415:331-341. [PubMed: 9889391]

Pharm Res. Author manuscript; available in PMC 2014 August 11. 
A

$\begin{array}{lllllllllllll}M \text { pDNA } 1 & 2 & 3 & 4 & 5 & 6 & 7 & 8 & 9 & 13 & 11 & 12 & 13\end{array}$

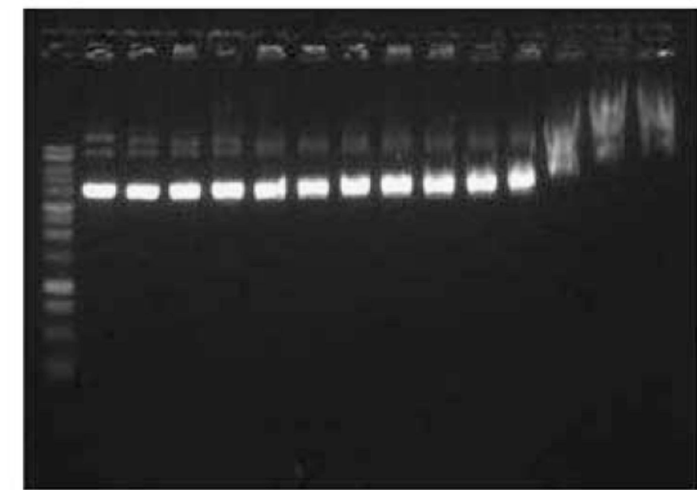

C
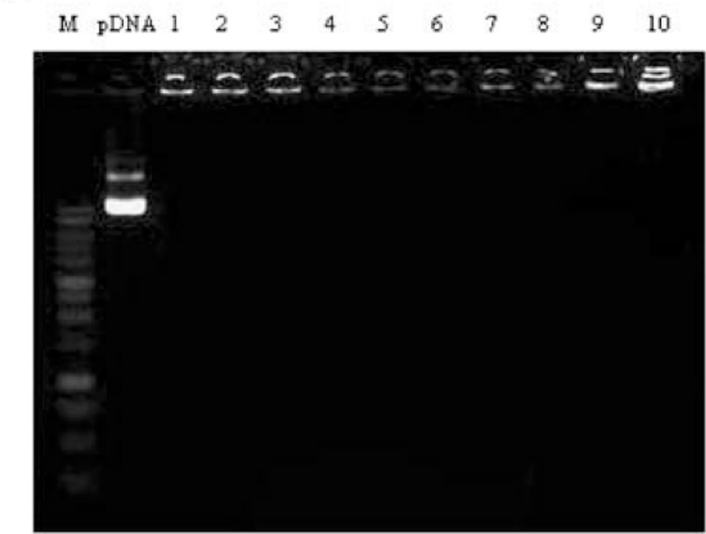

$\mathbf{E}$

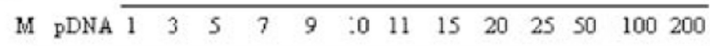

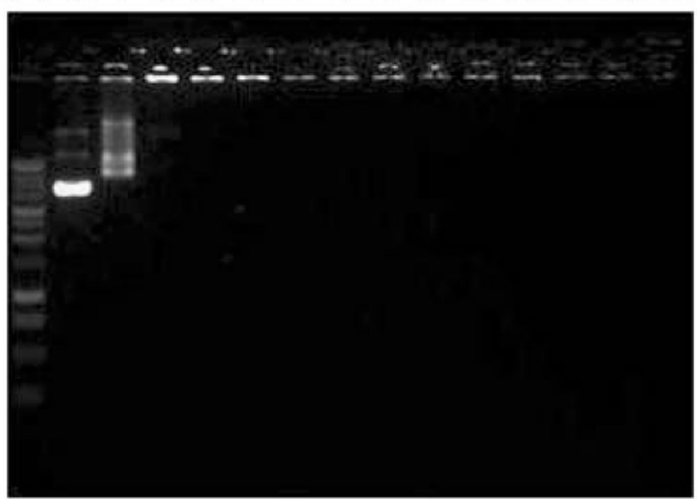

Fig. 1.
B \begin{tabular}{llllllllllllll} 
& N/P \\
\cline { 2 - 10 } & 1 & 3 & 5 & 7 & 9 & 10 & 11 & 15 & 20 & 25 & 50 & 100 & 200
\end{tabular}

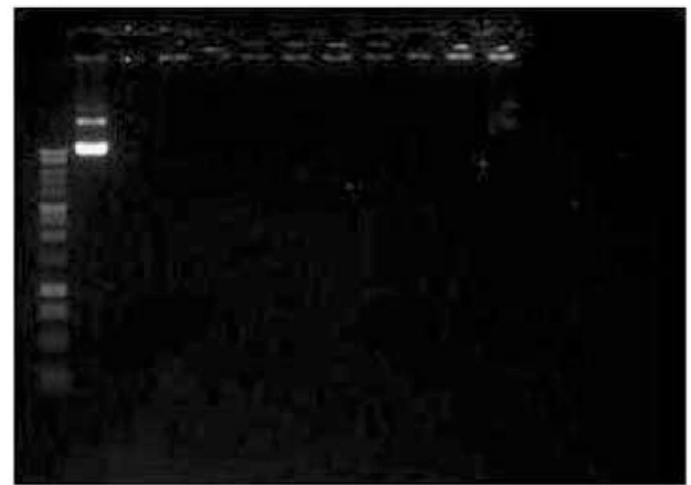

D N/P
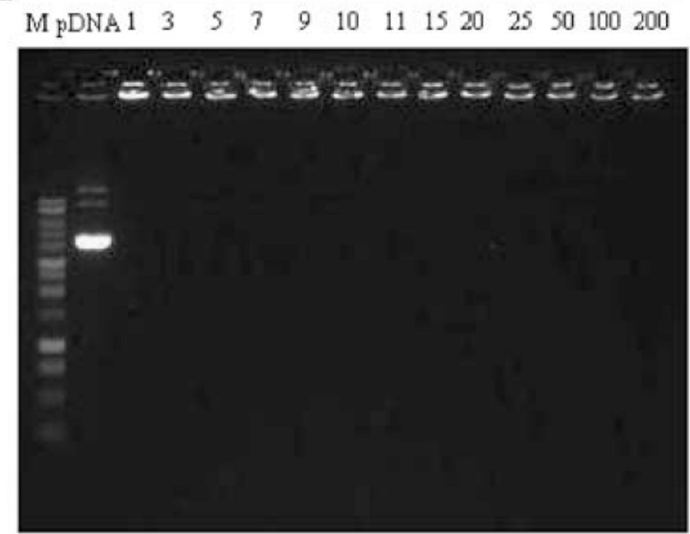

$\mathbf{F}$
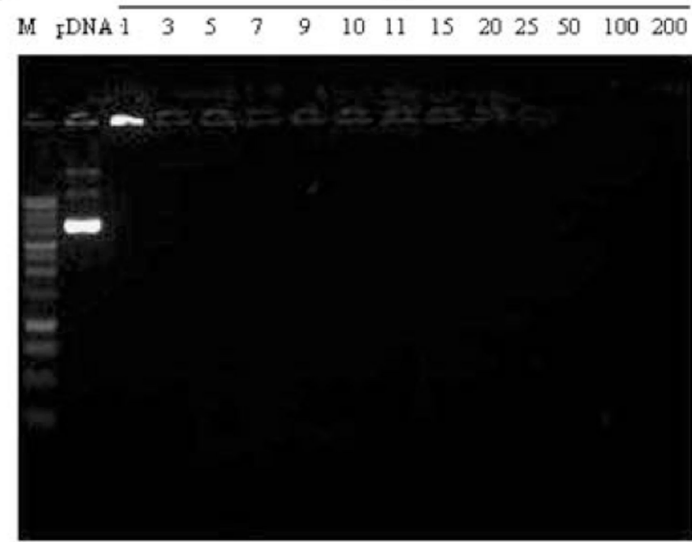

Gel electrophoresis study of (a) $\mathrm{CaCl}_{2} / \mathrm{pDNA}$ complexes; $1=0.1 \mathrm{M}, 2=0.2 \mathrm{M}, 3=0.3 \mathrm{M}$, $4=0.4 \mathrm{M}, 5=0.5 \mathrm{M}, 6=0.6 \mathrm{M}, 7=0.7 \mathrm{M}, 8=0.8 \mathrm{M}, 9=0.9 \mathrm{M}, 10=1.0 \mathrm{M}, 11=3 \mathrm{M}, 12=5 \mathrm{M}$ and $13=7 \mathrm{M}$ of $\mathrm{CaCl}_{2}$. (b) TAT/pDNA complexes. (c) TAT-Ca/pDNA N/P 25 complexes; $1=0$ $\mathrm{mM}, 2=62.5 \mathrm{mM}, 3=125 \mathrm{mM}, 4=250 \mathrm{mM}, 5=300 \mathrm{mM}, 6=350 \mathrm{mM}, 7=400 \mathrm{mM}, 8=500 \mathrm{mM}$, 9=1 $\mathrm{M}$ and $10=2 \mathrm{M}$ of $\mathrm{CaCl}_{2}$. (d) TAT/pDNA complexes with $0.3 \mathrm{M} \mathrm{CaCl}_{2}$. (e) Branched $\mathrm{PEI} / \mathrm{pDNA}$ complexes. (f) Linear PEI/pDNA complexes. 

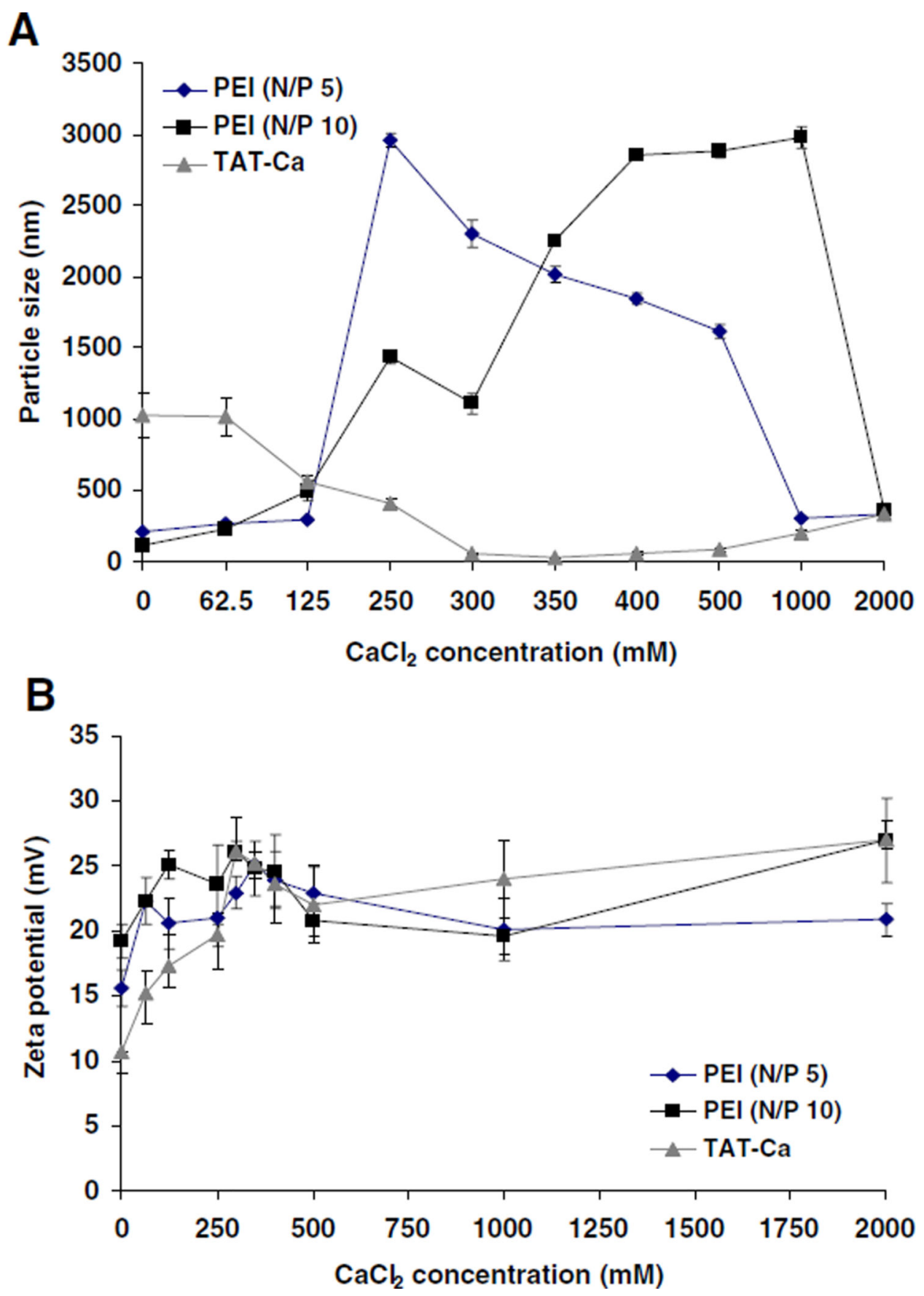

Fig. 2.

The effect of $\mathrm{CaCl}_{2}$ concentration on (A) particle size and (B) charge of PEI/pDNA complexes (N/P 5, N/P 10) and TAT-Ca/pDNA (N/P 25) complexes. Data are presented as mean $\pm \mathrm{SD}(n=3)$. 

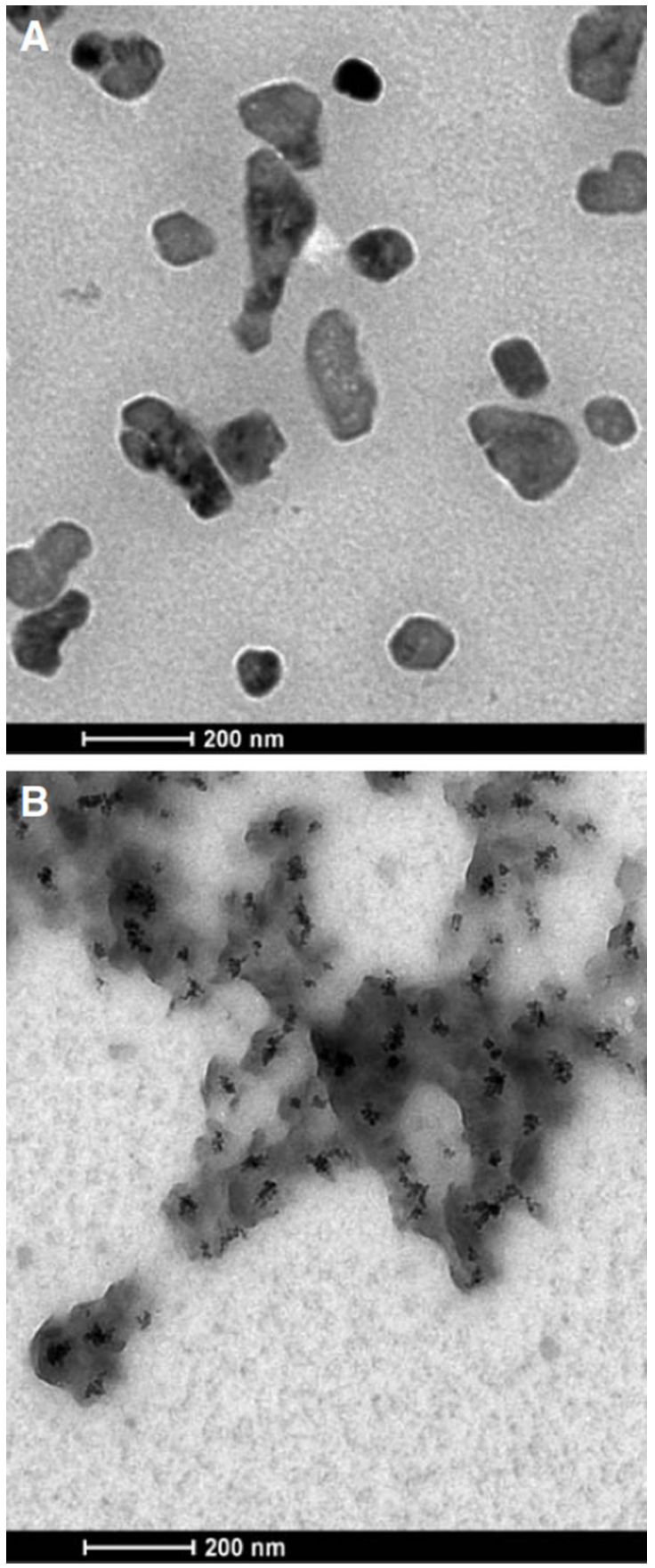

Fig. 3.

Transmission electron micrograph of (A) TAT/pDNA and (B) TAT-Ca/pDNA. 


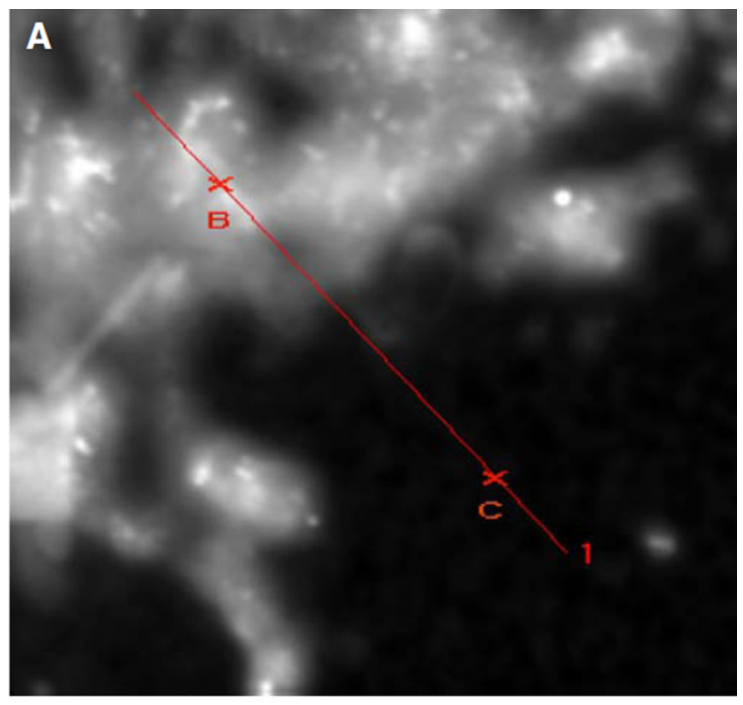

B

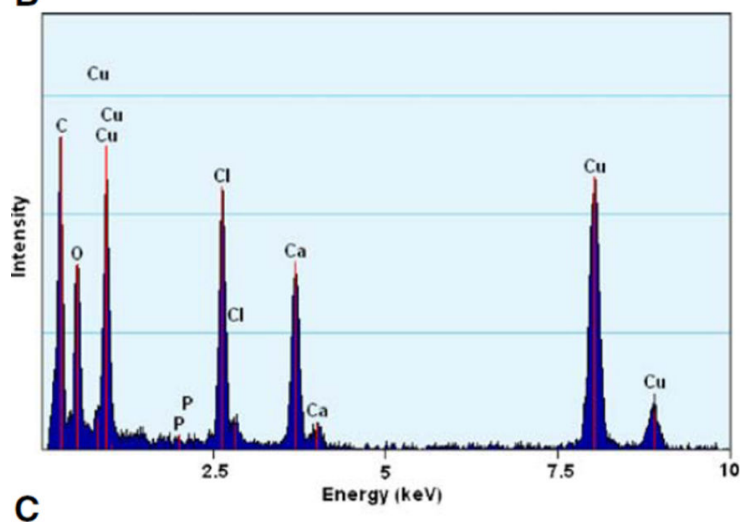

C

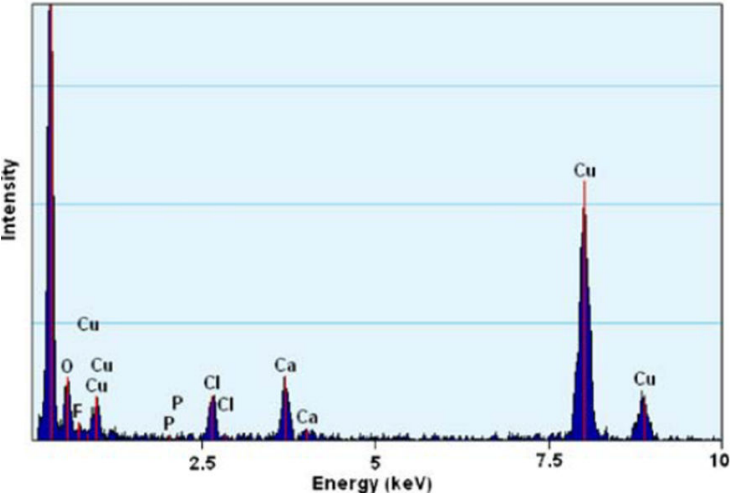

Fig. 4.

(A) Scanning transmission electron micrograph and EDAX spectrum of TAT-Ca/pDNA. The characterized areas (B) on particles and (C) on substrate are indicated in the scanning transmission electron micrograph. EDAX spectra showed the elemental composition of particles and substrate ( $\mathrm{Cu}$ peaks result from the copper grid). 


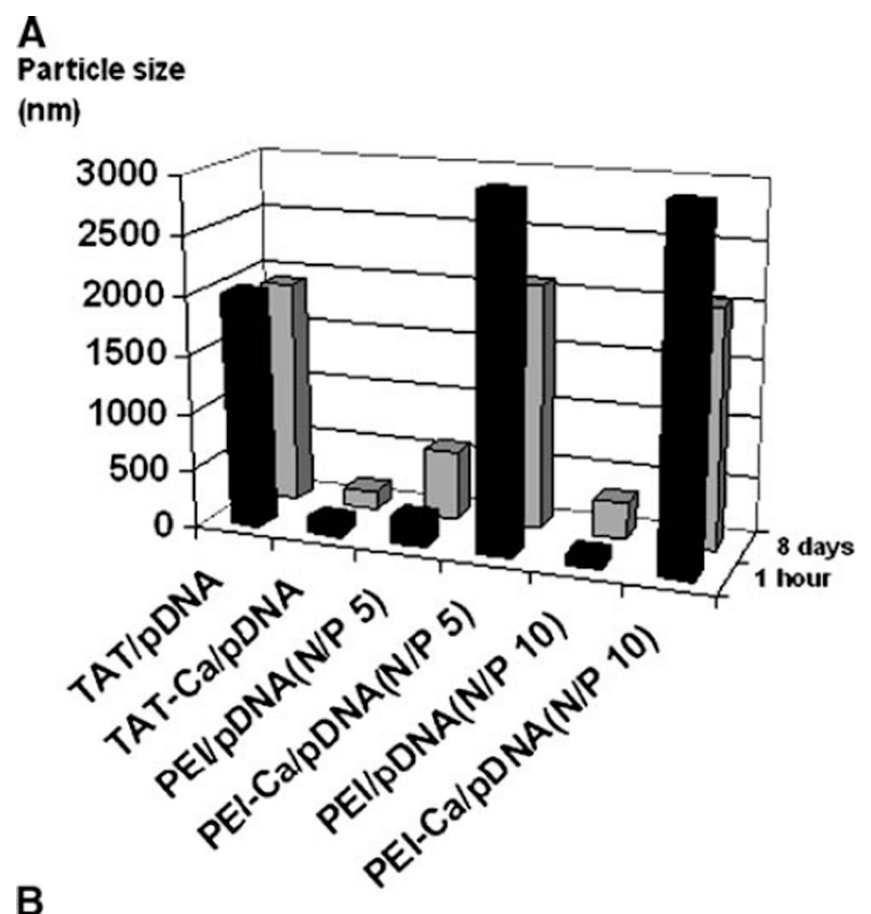

Particle size

(nm)

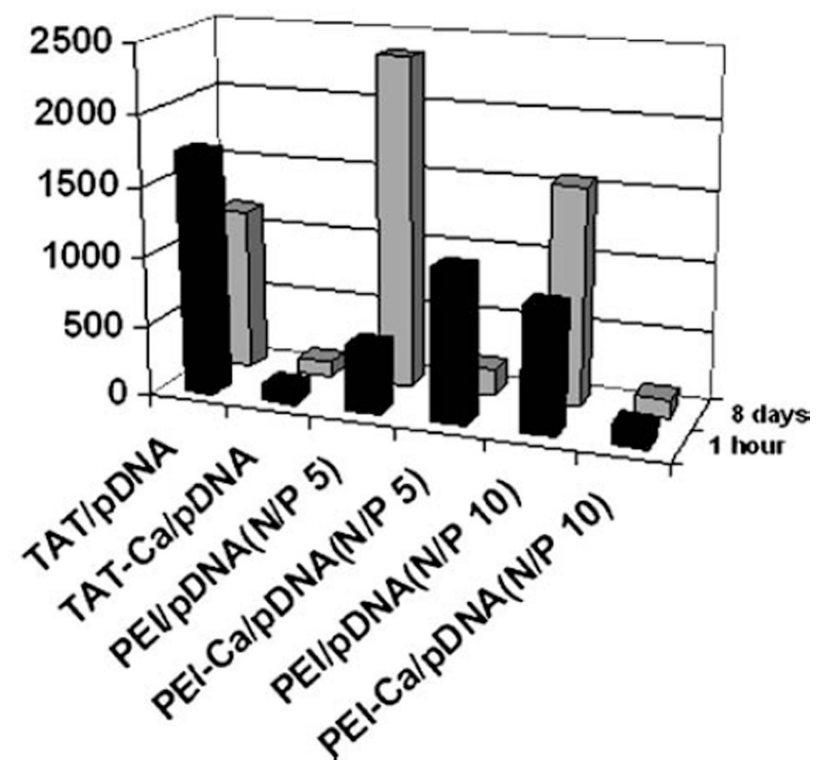

Fig. 5.

The stability of TAT-Ca/pDNA and PEI/pDNA complexes over time in (A) the absence and (B) presence of $10 \% \mathrm{FBS}$. Results are presented as mean $\pm \mathrm{SD}(n=3)$. 


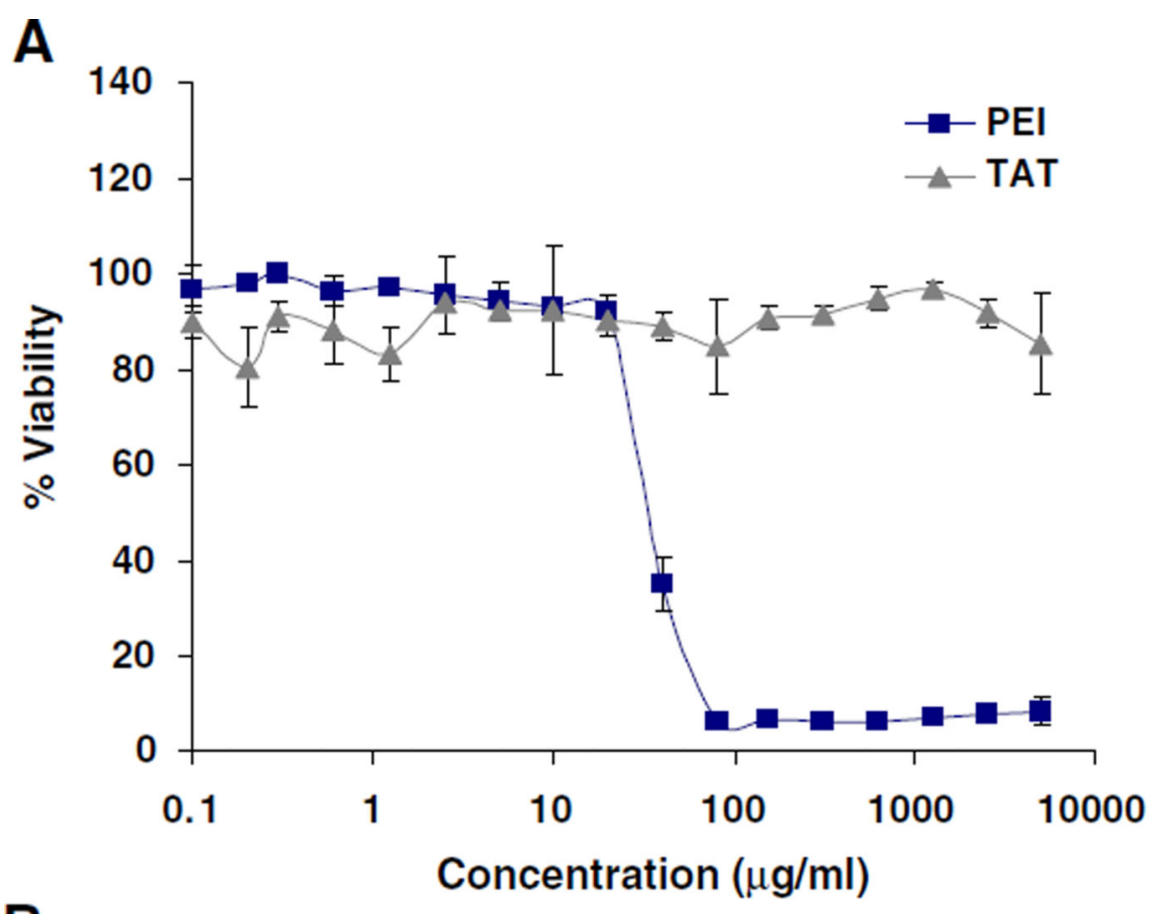

B

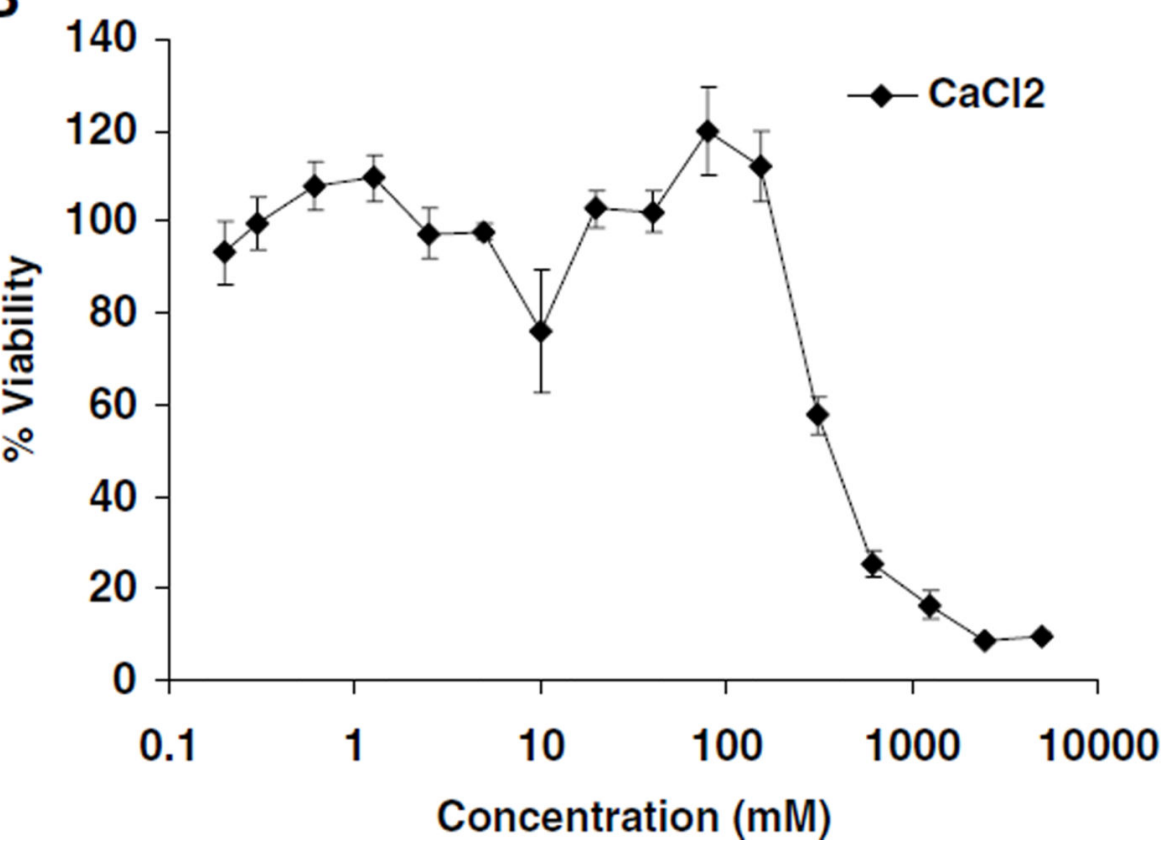

Fig. 6.

Cytotoxicity profiles of (A) PEI, TAT and (B) $\mathrm{CaCl}_{2}$. Viability is expressed as a function of polymer concentration. Results are presented as mean $\pm \mathrm{SD}(n=3)$. 


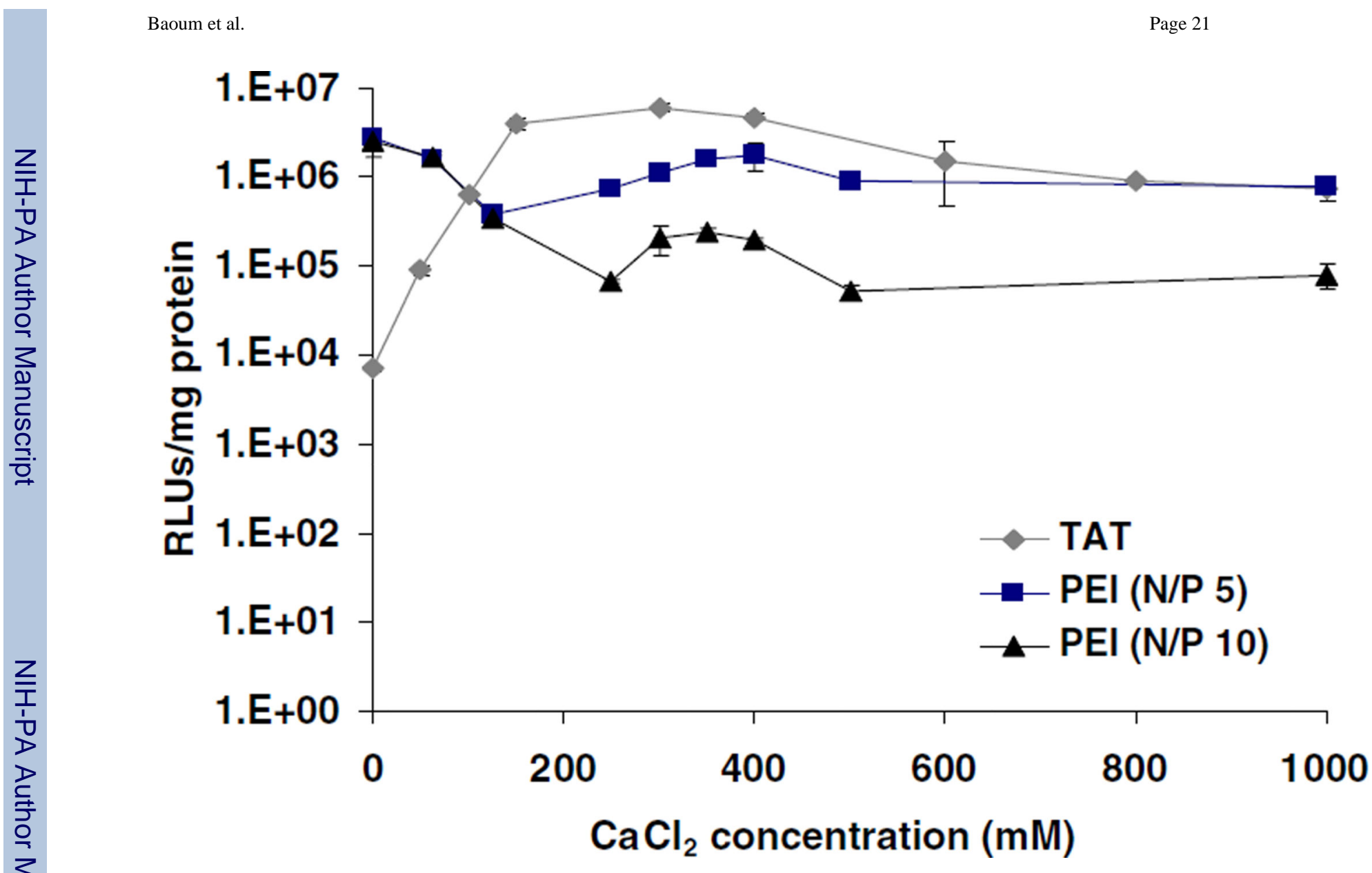

Fig. 7.

The transfection efficiency of TAT-Ca/pDNA and PEI/pDNA polyplexes with different concentration of $\mathrm{CaCl}_{2}$. Results are presented as mean $\pm \mathrm{SD}(n=3)$. 


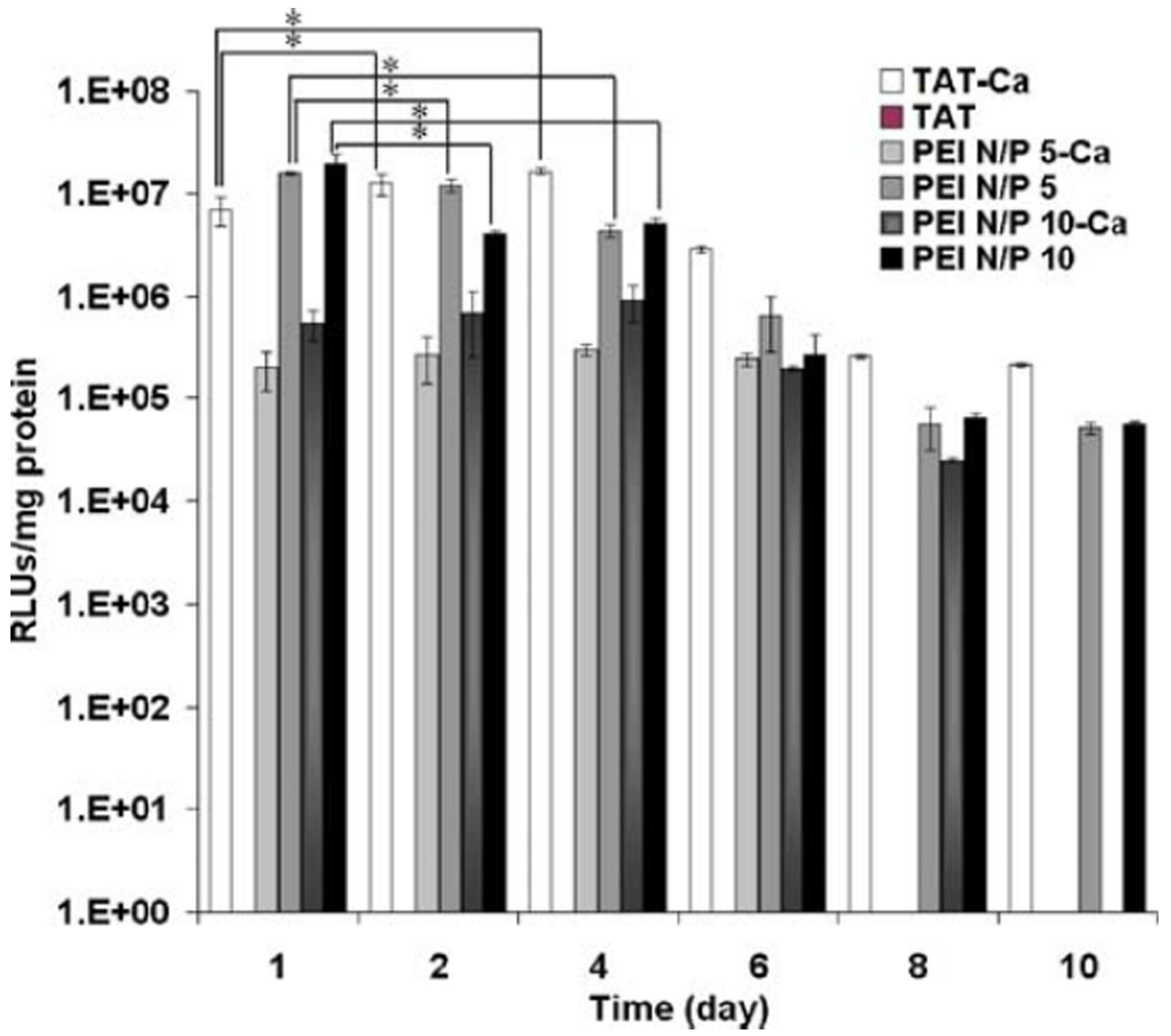

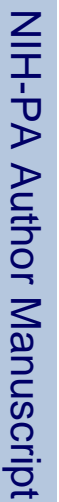

Fig. 8.

The transfection efficiency of TAT-Ca/pDNA and PEI/pDNA polyplexes with and without $0.3 \mathrm{M} \mathrm{CaCl}_{2}$. Results are presented as mean $\pm \mathrm{SD}(n=3) . * p<0.001$. 


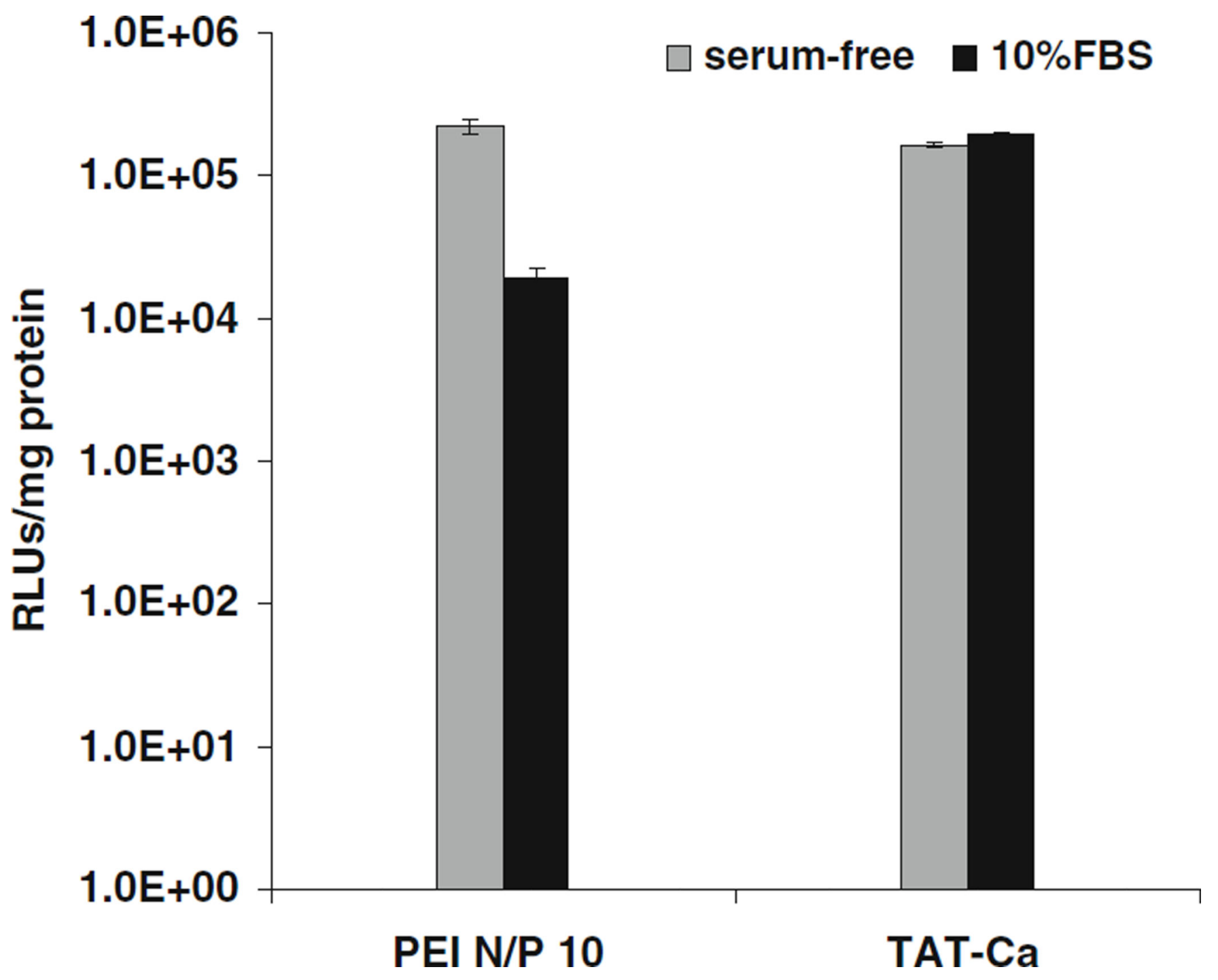

Fig. 9.

Transfection efficiency of TAT-Ca/pDNA and PEI/pDNA complexes in A549 cells in the absence or presence of $10 \%$ FBS. Results are presented as mean $\pm \mathrm{SD}(n=3)$. 
A

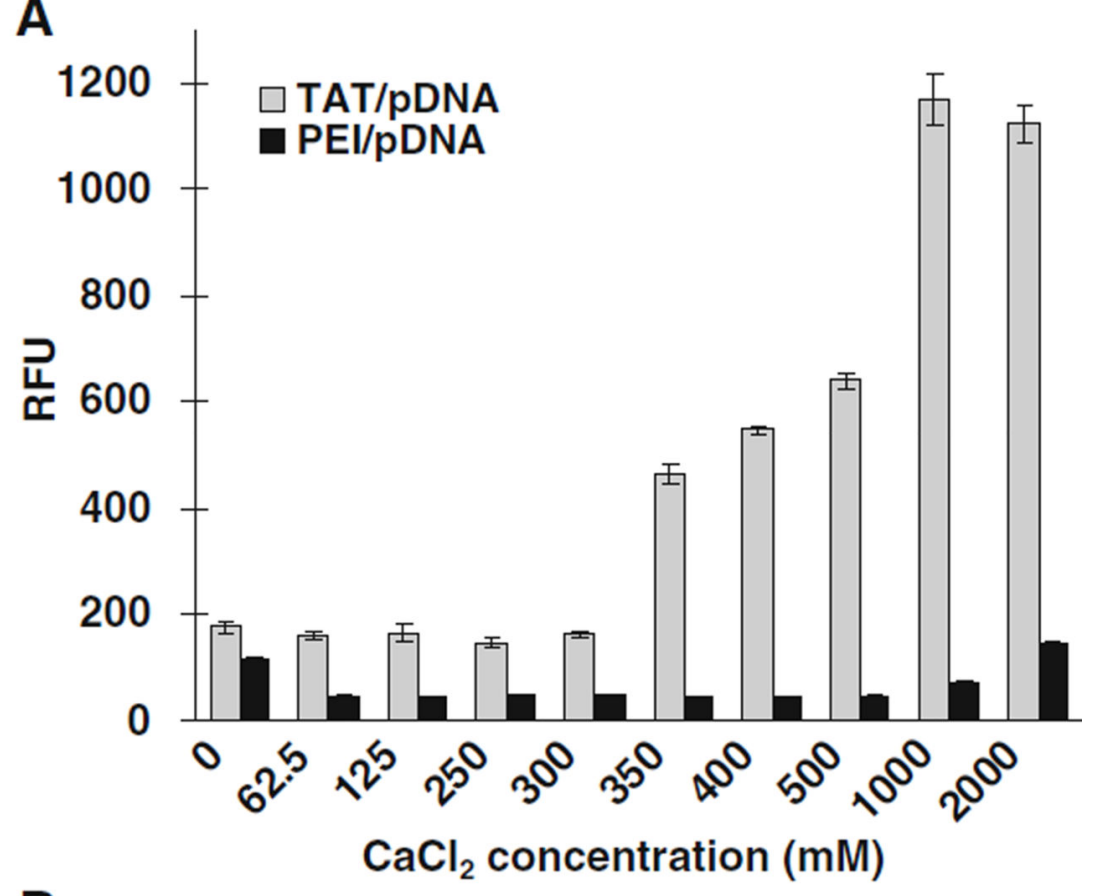

B

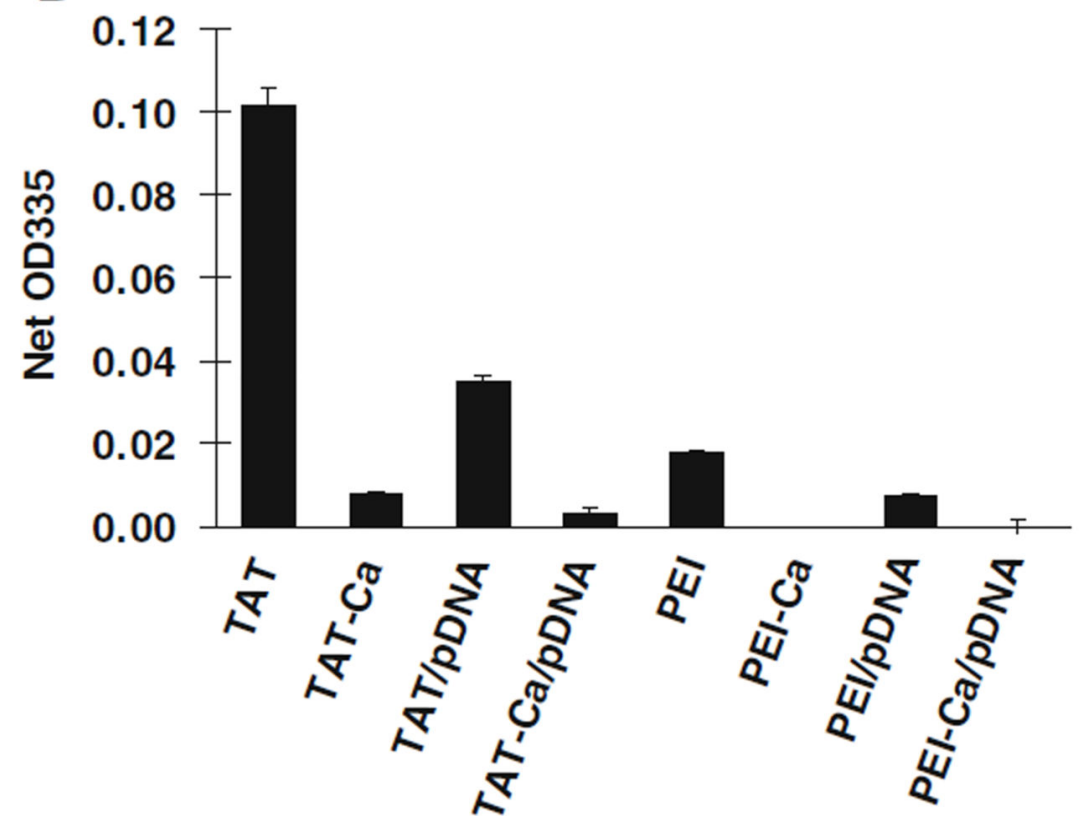

Fig. 10.

(A) Effect of $\mathrm{CaCl}_{2}$ concentration on the TAT/pDNA and PEI/pDNA complexes by using the SYBR Green assay to assess DNA accessibility and (B) condensation of TAT and PEI complexes assessed using the TNBS assay as a probe for amine accessibility. Results are presented as mean $\pm \mathrm{SD}(n=3)$. 


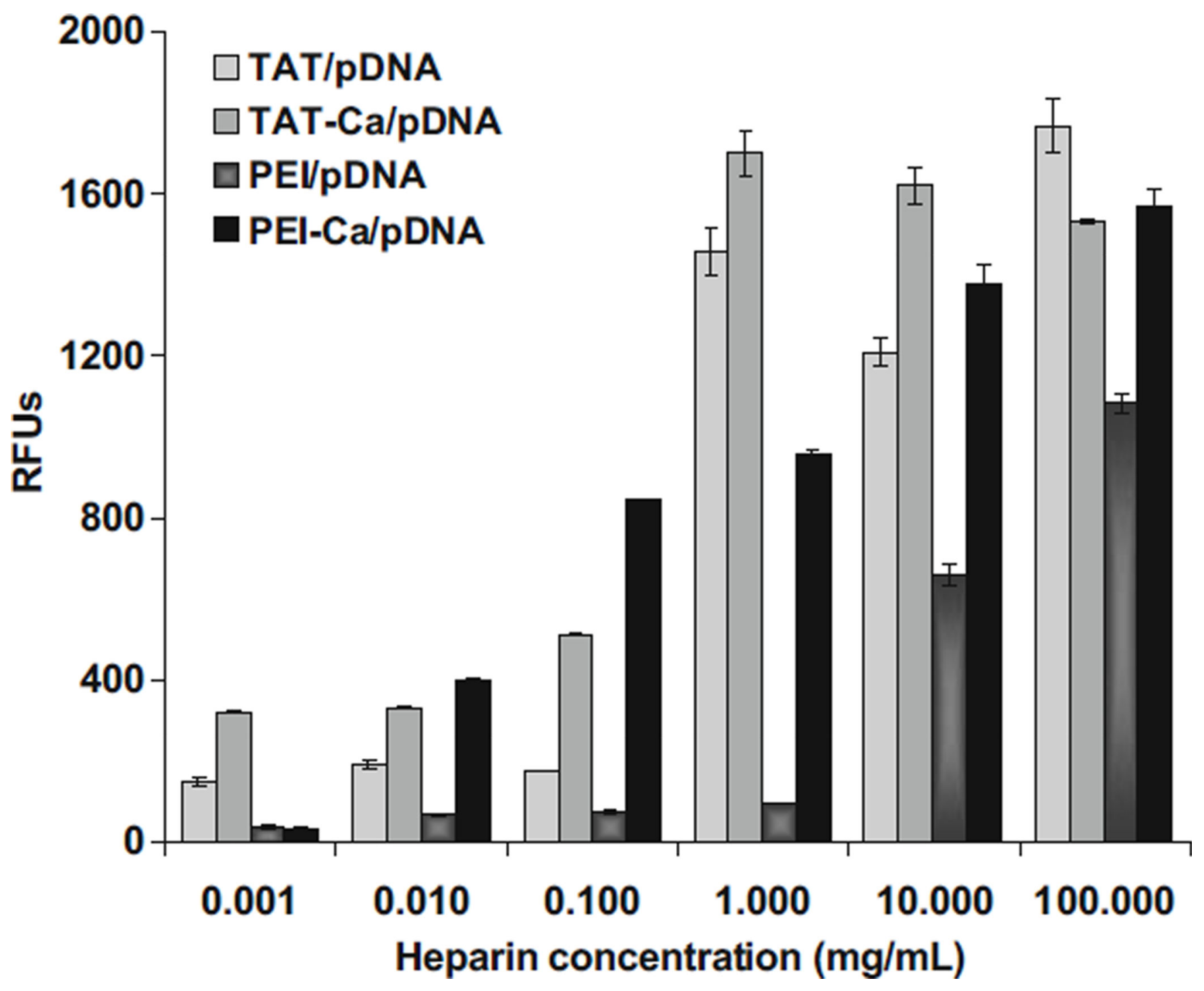

Fig. 11.

Unpackaging of TAT and PEI complexes by heparin displacement of DNA. Results are presented as mean $\pm \mathrm{SD}(n=3)$. 